\title{
Educational Values in Learning Dance Andhe-Andhe Lumut Art Studio Based on Panji Story Approaching Holistic Art Criticism
}

\author{
Yustiana Patrich Rosalia ${ }^{1}$, Slamet Subiyantoro ${ }^{2}$ Margana $^{3}$ \\ ${ }^{1}$ MastersProgram in Arts Education, Sebelas Maret University Surakarta, Indonesia \\ ${ }^{2,3}$ Faculty of Teacher Training and Education, Sebelas Maret University, Surakarta, Indonesia.
}

Email: patrich1203@gmail.com

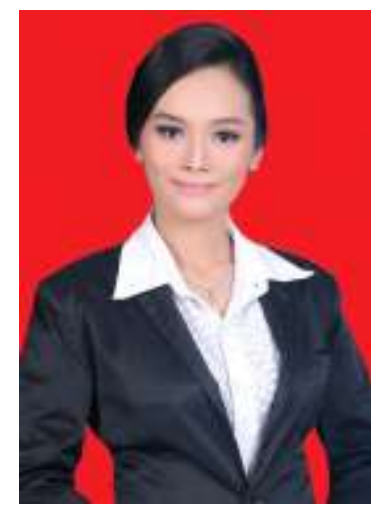

Yustiana Patrich Rosalia

Keywords:

Values, Learning,

Panji Stories,

Andhe -Andhe Lumut Art

Studio

\begin{abstract}
A B S T RA C T
This research is to examine the values in learning dance by utilizing sources of knowledge and local culture values about the Panji story as one of the cultural advantages of Kediri region. Learners ignorance of knowledge about the concept and purpose of dancing influences the learning of dance to be less creative. Problem that occur in learning dance at Andhe-Andhe Lumut art studio terms of practice where the teacher conveys the material is on the sensitivity of students in absorbing all information received, even students do not know the meaning of the movements and dance learned, as well as the educational values contained therein. Keep in mind that each motion has some meanings and that can be linked to the values of life of students widely. The methodology in this research is qualitative with a theoretical approach using holistic art criticism. The technique of collecting data through literature study, in-depth interviews, documentation, and observation with the analysis technique is descriptive analysis. It is to describe the data that has been collected. The results showed that the educational values contained in the learning of dance in these studios include aesthetic, moral, historical, social and cultural values. These values are expected to provide knowledge insights for young generation to understand, instill and maintain values in life obtained through dance learning.
\end{abstract}




\section{International Journal of}

Advanced Multidisciplinary Scientific Research (IJAMSR) ISSN:2581-4281

\section{Introduction}

Panji story as one of cultural advantages of Kediri area is a local cultural value for the revitalization of education in Indonesia and can be used as learning material for young generation. Revitalizing local culture values as an effort to develop education in Indonesia, which implies the maintenance and preservation of local culture and demonstrates local identify. Learning in an activity as a result of memory, cognition, metacognition and information processing (Huda, 2013:2). Learning occurs through experiences to deepen reflection and integrate theories with practice (Sajnani, et al.,2020:2). Learning is of course included in educational process that affects the development of children to see, absorb and receive all information by teacher to students. Therefore, learning can be interpreted as a process of changing behavior through various experiences that refer to the potential development of a person who is noble, intelligent and virtuous.

Learning dance at Andhe-andhe Lumut art studio is a form of non-formal educational institutions. The benefits of art education in non-formal educational institutions are for profession and self-improvement for personality formation in accordance with the goals of national education. Sicherl-Kafol argues that learning process will bring new qualities for personal development and achieve learning goals (Sicherl-Kafol, et al.,2010:4697). Thus, the art studio supports national education goals through learning the art of dance. This studio founded by Sugeng and Nur Setiani located in Cakruk Village, Banjaranyar, Kras, Kediri regency. Based on data obtained through interviews, this art studio is a place for learning and developing the potential, talents, and interests of children in the art world (Studio owner, October 2019 interview). As stated by Tjejep Rohadi in Resi, within the studio system children can learn easily because the trainer will focus on providing material about this field and children become more active and creative individuals (Resi, 2019:403). It can be said that the studio is a meeting between the trainer and a group of students who carry out of art learning activities.

One of the problems in learning dance activities at Andhe-andhe Lumut lies in the ignorance of students regarding knowledge of the concepts and goals of dancing. The teacher does not explain of the concept or background 


\section{International Journal of \\ Advanced Multidisciplinary Scientific Research (IJAMSR) ISSN:2581-4281}

of dance, so that students do not know the meaning of movement and the values of dance learned from this. Freire defined that understanding the value of art in education can be obtained through learning by gathering local information and life experiences (in Sajnani, et al., 2020:2). So it can be understood that in learning the art of dance contains a variety of meanings that can be related to the values of life and local cultural values.

Based on the explanation above, it can be found a phenomenon that is worthy of study, namely by describing the values of education in learning dance provide insight into knowledge and meaningful learning experiences for children to achieve national goals, especially through learning dance.

\section{Methods and Materials}

This paper is the result of research at Andheandhe Lumut Kediri art studio related to learning dance. Research data were obtained through: (a) non-participant observation or direct observation in the field during the learning process; (b) documentary study, namely documents in the form of reading material or written data which are also photographs during learing activities; (c) indepth interviews with studio owners, dance trainers or teachers, as well as with the parents of students, which were conducted by giving an open statement through a questionnaire. The data analysis technique used is the Flow model (Miles and Huberman in Sugiyono, 2019:321) that the analysis activity is carried out interactively and takes place continuously to completion (see Figure 1).

Figure 1 Shows A Data Collection Period

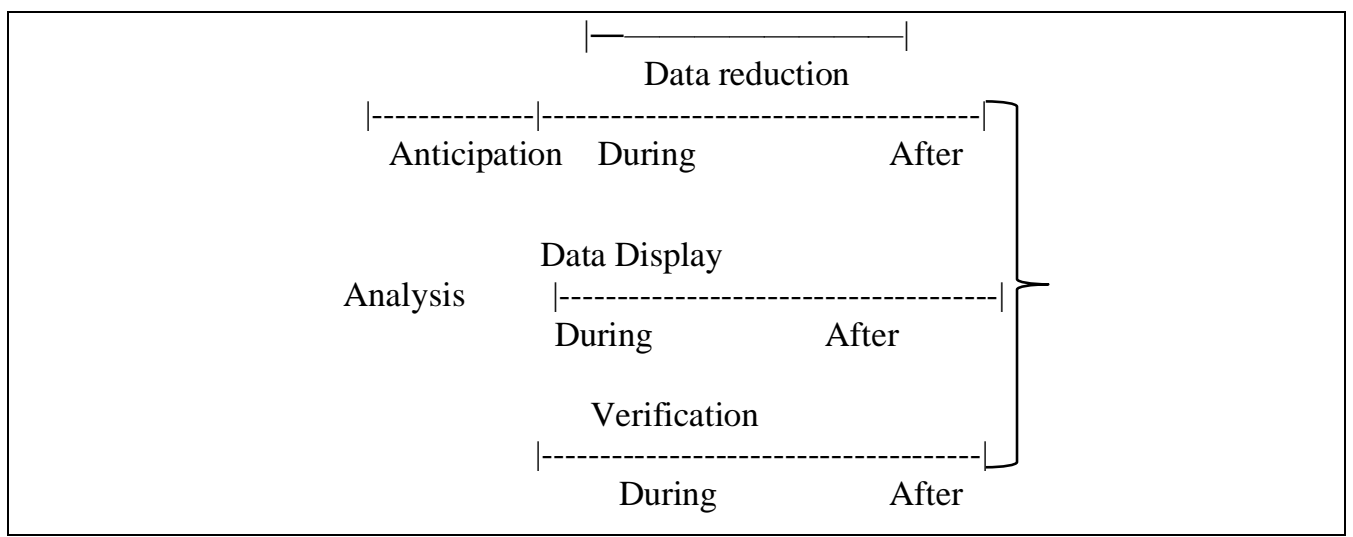

Figure 1. Components of Flow Model Data Analysis

(Miles and Huberman in Sugiyono, 2019:322) 
Vol 3, Issue 10, 2020 Imfact Factor:2.58 DOI: https://doi.org/10.31426/ijamsr.2020.3.10.3815

\section{International Journal of \\ Advanced Multidisciplinary Scientific Research (IJAMSR) ISSN:2581-4281}

\section{Results and Discussion}

This study uses a holistic art criticism approach, where the quality of the phenomenon being studies is based on background or genetic factors are related to formal conditions in the form of reality and affective factors in the form of responses from people who interact with the program evaluated (Sutopo, 2006:144).

\section{Genetic Factors}

This factor is related to the initial context before the program was implemented along with the formation process (Sutopo, 2006:144). Based on this statement, this factor is an idea that embodies a studio being formed as a formal reality. The background of the establishment of Andhe-Andhe Lumut Kediri art studio is to form an art organization that preserves traditional cultural arts, develops existing cultural arts so that it can go along with the journey of technology, is a non-formal learning or learning activity in the context of character education, introducing Kediri ethnic art with its historical background of Panji story and providing space for creation and innovation as well as support for young generation to become qualified artists (Deed of Notary Andhe-andhe Lumut Art Studio, article 2). The vision and mission of establishing the study is in line with the view of education, namely that education is an effort to develop self-potential and preservation of cultural values (Jalaluddin and Abdullah, 2018:200). Likewise, with $\mathrm{KH}$ Dewantara opinion that education is generally intended to promote the growth of character, mind and body of children (in Wenti Nuryani, Suminto\& Dwi, 2020:311). So, it can be understood that education through learning the art of dance by utilizing the local cultural values of Kediri helps the government direct the young generation to improve character, mutual respect and respect in life at large. To make it easier to understand the purpose of establishment, it can be seen in table 1. 


\section{International Journal of}

Advanced Multidisciplinary Scientific Research (IJAMSR) ISSN:2581-4281

Table 1. Form of Activities to Establish a Studio

\begin{tabular}{|l|l|l|}
\hline No & \multicolumn{1}{|c|}{ Material } & \multicolumn{1}{c|}{ Form of Learning } \\
\hline 1 & $\begin{array}{l}\text { Traditional art values and local wisdom } \\
\text { of Kediri (Panji stories, jaranan } \\
\text { traditional arts and Kediri folk tales) }\end{array}$ & $\begin{array}{l}\text { Organizing teaching and learning process activities in } \\
\text { the field of dance and musical arts; organizing dance } \\
\text { workshop with the education office; dance and } \\
\text { musical performances; creating works of dance and } \\
\text { musical arts; rent out clothes for dance equipment. }\end{array}$ \\
\hline 2 & Technological development & $\begin{array}{l}\text { The study remains active and is able to survive } \\
\text { presenting and creating dance works that prioritize } \\
\text { local cultural values of Kediri. }\end{array}$ \\
\hline 3 & Studio as non-formal education & $\begin{array}{l}\text { Learning takes place as an effort to instill educational } \\
\text { values and will be growth the character of students. }\end{array}$ \\
\hline
\end{tabular}

Andhe-Andhe Lumut Kediri art studio as inauguration took place, since January 10, 2015 described above is a non -formal educational institution which was inaugurated in front of a notary on January 17, 2019. Even though it has (Deed of Establishment, article 3). This studio divides several sections for grouping of students (see table 2).

been running long enough before the

Table 2. Grouping of Students

\begin{tabular}{|l|l|l|l|}
\hline \multicolumn{1}{|c|}{ No } & \multicolumn{1}{|c|}{ Group } & \multicolumn{1}{c|}{ Category } & \multicolumn{1}{c|}{ Dance Material } \\
\hline 1 & A1-A2 & Paud age and grade 1-3 & $\begin{array}{l}\text { Ujung Tiban dance, Tiban Kedhiren dance, Engklek } \\
\text { dance (nuances cheerful, happy, simple and easy to } \\
\text { studied). }\end{array}$ \\
\hline 2 & B & $\begin{array}{l}\text { Grade 4-6 and junior } \\
\text { high school }\end{array}$ & $\begin{array}{l}\text { Sekar Wilis dance, Tunggul Wulung dance, Greget } \\
\text { Jaranan dance (dance is more dynamic, agile and } \\
\text { assertive). }\end{array}$ \\
\hline 3 & Teena-ger & $\begin{array}{l}\text { Junior and senior high } \\
\text { school }\end{array}$ & $\begin{array}{l}\text { Topeng Panji dance, Cundrik Asmarantaka } \text { dance, } \\
\text { Bedhaya Candrakirana } \text { dance, Sang Kirana dance ( } \\
\text { more expressive, difficulty levels and implies the } \\
\text { values of life). }\end{array}$ \\
\hline
\end{tabular}

Based on data through that interview the grouping of studios is used for providing space for the learners in to create and innovate to be a worthy artist, where the young generation becomes independent and able to study and create dance art without losing its values of education, especially local cultural values Kediri (studio owner, April 2020 interview). Andhe-andhe Lumut Kediri art studio has showed some of the achievements (see table 3 ). 
Table 3. The Achievements of the AndheAandhe Lumut Kediri Art Studio

\begin{tabular}{|l|l|l|}
\hline \multicolumn{1}{|c|}{ No } & \multicolumn{1}{|c|}{ Year } & \multicolumn{1}{c|}{ Achievement } \\
\hline 1 & 2019 & Collaboration Award charter Art and Culture of Guruh Soekarno Putra \\
\hline 2 & 2016 & $\begin{array}{l}\text { Festival Award charter Art from the Managing Director Taman Mini } \\
\text { Indonesia Indah, Jakarta }\end{array}$ \\
\hline 3 & 2016 & $\begin{array}{l}\text { Appreciation Award certificate artist achievement against Cultural Arts } \\
\text { Development in East Java }\end{array}$ \\
\hline 4 & 2013 & Featured works Festival Presenters East Javanese Dance \\
\hline 5 & 2013 & $\begin{array}{l}\text { Art Degree Award Charter Regional Culture of the Culture and Tourism } \\
\text { East Java Province }\end{array}$ \\
\hline 6 & 2010 & $\begin{array}{l}\text { Festival Award charter Arts from the Department of Education East Java } \\
\text { Province }\end{array}$ \\
\hline 7 & 2009 & Best Presenters of Student Art Week East Java Province \\
\hline
\end{tabular}

\section{Objective Factors}

Objective information sources are obtained through observation of reality or formal conditions include a variety of things relating to the elements that exist through works, events or programs evaluated (Sutopo, 2006:144). Art learning dance at Andhe-andhe Lumut Kediri art studio is a non-formal education institution capable of developing talented students in the art of dance. Shape learning carried out in the studio in the form of provision of physical skills, namely movement skills, quality of motion, proficiency motion, the strength of motion is good flexibility, balance and memorization of dance. Erikson stated that if all participants want the students are successful in developing skills then a model is needed in learning and meaningful activities to enrich children learning experiences (in Sichrel-kafol, et al.,2010:4696). However, provision of skills provided in the studio have short comings where the students do not know the meaning of dance movements learned. Please note that it is a deep dance learning not only equipped with dance movement skill only, but also the provision of knowledge from the dance that learners learnt so that participants really understand the importance of the meaning of motion and dance that contains values of education. Efforts to achieve that goal is to choose proper learning performed by a dance teacher or coach to learners with direction from the leader of studio. Studio leaders prepare and design learning programs and equip the teachers. In tune with opinion Sööt and Ele (2014:291) that teachers must equip herself that is with the ability to evaluate, analyze and make an assessment of teaching practice to 


\section{International Journal of Advanced Multidisciplinary Scientific Research (IJAMSR) ISSN:2581-4281}

students. Thus, learning what is effective is to pay attention that the education process is an activity transfer grades, so teacher attendance is provide design facilities and direction of purpose learning to bring about meaningful result and useful learning.

\section{Learning with the Bloom Model Approach}

Benjamin Bloom identifies this realm with the cognitive domain taxonomic model includes memory or recognition of facts certain facts and concepts that are enabling the development of abilities and intellectual skills (in Huda, 2013:169). Bloom define learning by taxonomy for cognitive includes knowledge understanding, use, analysis, synthesis and evaluation; for affective includes activities accepts, react, accept and arrange values and character development; while psychomotor includes great movement, movement smooth, nonverbal and communication skills speaking (in Sichrel-Kafol, et al., 2010:4697). So, the Bloom model can be done learning or teaching and learning activities provide knowledge or concept introduction about a movement and dance can help learners to understand the ability in thinking. There are six main categories start from the simplest behavior to the most complex. The classification is based on the first three levels (Bloom in Ozlem, et al.,2012:1136) namely knowledge, understanding and application as a lower cognitive level and the last three levels, namely analysis, synthesis and evaluation as an upper cognitive level (see table 4).

Table 4. Learnings stages of Bloom's Taxonomy

\begin{tabular}{|l|l|l|l|}
\hline \multicolumn{1}{|c|}{ No } & \multicolumn{1}{|c|}{ Strategy/ material } & \multicolumn{1}{|c|}{ Teacher activity } & \multicolumn{1}{c|}{ Student activity } \\
\hline 1 & Knowledge & $\begin{array}{l}\text { Explain the background or concept } \\
\text { of dance }\end{array}$ & $\begin{array}{l}\text { Note, remember or listen data and } \\
\text { information }\end{array}$ \\
\hline 3 & Comprehension & $\begin{array}{l}\text { Explain type or variety and } \\
\text { meaning dance moves }\end{array}$ & $\begin{array}{l}\text { Understand type, variety and meaning } \\
\text { of motion dance }\end{array}$ \\
\hline 4 & Application & $\begin{array}{l}\text { Demonstrate range of motion } \\
\text { dance, to do training over and over } \\
\text { reset accordingly with tempo } \\
\text { dance accompaniment }\end{array}$ & Take into account right and mimic \\
& Analysis & $\begin{array}{l}\text { Contact mate meaning motion in } \\
\text { life learners }\end{array}$ & $\begin{array}{l}\text { Able to understand mean related with } \\
\text { life daily }\end{array}$ \\
\hline 5 & Synthesis & $\begin{array}{l}\text { Mention and explain the values } \\
\text { education }\end{array}$ & $\begin{array}{l}\text { Find importance values education and } \\
\text { implementation in our life }\end{array}$ \\
\hline 6 & Evaluation & $\begin{array}{l}\text { To do assessment } \\
\text { Presenting part of dance and range of } \\
\text { motion dance; performance of dance } \\
\text { in a manner intact with dance } \\
\text { accompaniment in a manner } \\
\text { independently }\end{array}$ \\
\hline
\end{tabular}




\section{International Journal of \\ Advanced Multidisciplinary Scientific Research (IJAMSR) ISSN:2581-4281}

\section{Educational Values in Learning Dance Based on Panji Story}

Values is an abstract reality, however very basic and guides in human life (Sitohang, 2018:157). Value is a life force for the person and the community (Sanusi, 2015:180). Then, it can be understood that value is something that is useful and beneficial to humans and can used a reference in everyday life dyas to improve the quality of life. Learning dance based on Panji story has historical, social, culture, aesthetic and moral value.

\section{Panji Story as an Understanding of Historicity Values}

Socrates in Sitohang stated that history is a human learning process to remember and be aware of things he knows implicitly (2018:194). The statement understood that when humans reflect on existance and search for the meaning of life humanity and historicity, then that human being make a more precise understanding about her past experiences. Xavier Zubiri stated that history is a movement procedural consisting of two moments, namely the first moment and the next moment supported by the previous moment (in Sitohang, 2018:195). Procedural movement it means that every moment of history moves from one moment to the other moment. Both statements above can be formulated that the essence of history is closely related to the learning process of discovering experiences of human life in the past that can be presented again in the present and the future. The learning process is a part of the journey to find identity to know and understand it better. Teak self-shows who, what, and how to interpret life experiences humans become useful in the present and the future.

Various forms and media that can be used to recognize and understand identity is through history, one of which is through culture. The culture is recorded through it are events that make history. The event will arouse memory as a nation that learns against the strong identification process of each individual to study about history. Strong identification occurs when each individual feels historical three things. First, human testimony to produce something in all of its activities. Activity produces great works which are as awesome as the temple Borobudur, Prambanan or works written scattered all over archipelago. These works are interpreted as a living testimony about the past events regarding costumes, beliefs, literature, and buildings or cultural 


\section{International Journal of Advanced Multidisciplinary Scientific Research (IJAMSR) ISSN:2581-4281}

heritage. Second, the spread of values; history is understood not only as events for testimony in the past alone, but also related to that value hidden. Francis Fukuyama stated that digging for the value behind history for development society is the main goal of historical studies (in Sitohang, 2018:196). Then that value is open and disseminated to be part of the essence of history. Third, the transmission of reality; reality is the possibilities of the human way are on. Humans can repeat these possibilities at the same, however it can also be a different way from that time. The past as reality does not exist, however the possibilities in the past is used as a reference.

Kediri in its heyday deep writing history has had an urgent role. The history that was written produced a record of the heyday of Javanese literature ancient. A literary work that is famous is Panji story. Panji story is a story that has got enough attention of some experts. Poerbatjaraka states that Panji story as a part of the old history of Java island. The story experienced by Panji whose last name is Inu Kertapati already known by a European Javanese linguist expert (Poerbatjaraka, 1968:XVII). Panji's experiences published in various texts make up stories. Panji received non-existent attention end. Berg in that Poerbatjaraka Panji stories is written form in old Javanese later translated or adapted into Melayu language (Poerbatjaraka, 1968:403). Panji's story by Berg also called hero stories from Java. It is already popular within the palace of the king of East Java. The spread of the Panji story has reached Bali, Lombok, Sulawesi, Sumatera, Malaysia, Thailand and Cambodia with various version adapted to the local genius and community conditions (Poerbatjaraka, 1968:400). The events of spreading Panji story have occurred provide that Kediri provides historical incisions on the regional, national level and even international. Dance education at this studio is one of the forms of means of understanding the value of historicity which can be seen in table 5 .

Table 5. Implementation of Historical Meanings

\begin{tabular}{|l|l|l|l|}
\hline \multicolumn{1}{|c|}{ No } & \multicolumn{1}{|c|}{ Historical Meaning } & \multicolumn{1}{c|}{ Teacher activity } & \multicolumn{1}{c|}{ Student activity } \\
\hline 1 & Testimony of Human & $\begin{array}{l}\text { Give dance material with the } \\
\text { background Panji story }\end{array}$ & $\begin{array}{l}\text { Receive knowledge and become } \\
\text { witness deployment Panji's story } \\
\text { through the material dance }\end{array}$ \\
\hline 2 & Spreader value & $\begin{array}{l}\text { Explain values education in story } \\
\text { history }\end{array}$ & $\begin{array}{l}\text { Understand knowledge and values of } \\
\text { education }\end{array}$ \\
\hline 3 & Forwarding reality & $\begin{array}{l}\text { Forward values and meaning life } \\
\text { to learners }\end{array}$ & $\begin{array}{l}\text { Receive and go on values life into the } \\
\text { environment family and the public }\end{array}$ \\
\hline
\end{tabular}




\section{International Journal of \\ Advanced Multidisciplinary Scientific Research (IJAMSR) ISSN:2581-4281}

\section{Panji Story as Value Cultivation Sociality}

Sociality as part of the dimension human and is a reality or fact of human daily life (Sitohang, 2018:116-132). These dimensions lead to a reality that humans live every day. Reality includes the awareness that there are other people as a result of social life. Buber in Sitohang (2018:116) that there are two forms of fundamental relations that accompanies human life, namely relationships human with fellow human. Buber asserts that with two relation forms it is concluded that:

\section{"...humans are always in touch with another human. It just forms yourself in the company of others. But it is not just formed by people others, but also shape other people. Thus, apart be personal because of everyone else, each personally have a duty to make others become personal".}

This statement can be understood, that each individual has a personal function that is, develop oneself and social function, that is helping develop other people. Hanefi stated that dance as an art product is part of people culture and the result of the expression of the reality in life (in Indrayuda, 2016:145). It can be understood in the reality of life that it cannot be separated from the relationship of human behavior. Viewed from an anthropological perspective, dance is a product human behavior related to supporting the socio-cultural life of society (Indrayuda, 2016:145). The products of human behavior can be found in the Andheandhe Lumut Kediri art studio involves dance coaches and learners forming interactions. These interactions show a lifelike and develop according to the nature of humanity because of the other person presence. So as with interactions that occur and take place during the process of learning dance at this art studio. Interaction shown by students receiving communication from the teacher and the relationship has a higher value (Sajnani, et al., 2020:3). As for the values of sociality: fairness, responsibility, solidarity, trust, exemplary, and ethics. First, fairness is human true to be himself as long as he is open up and unite with each other (Sitohang, 2018:124). This value creating good relationships and dialogue between dance coaches and students. Good relationships and dialogue are open to others and are active. Students act more introducing oneself to others and expressing reactions, their reactions and life experiences to others in the learning process. Second, Emmanuel Levinas views are quated by Sonny Keraf that the responsibility towards others are basic and existing moral principles without being selected (Keraf in Gilligan, 1997:xviii). 


\section{International Journal of Advanced Multidisciplinary Scientific Research (IJAMSR) ISSN:2581-4281}

Responsibility is an activity human life as a social being by giving and receiving. Both of them are mutually filling and balance as a form of dynamics human sociality. Likewise, with the process of dance education that takes places in the studio has created an attitude of responsiveness by receiving learning materials well. Dance coaches and students have consciousness of obligation toward freedom of each person to live and grow with an attitude of responsiveness in culture and actions of uplifting the values of the lives of others. Third, according to Scheler's that it places solidarity as an actual attitude in society (in Sitohang, 2018:126). Solidarity is a principle closest to experience of human life that can unite everyone in a community.
Likewise, with the learning in the art studio which is an arts organization for unite each student through attitude of good solidarity between the dance coach fellow students for appreciating each other. Fourth, trust; Francis Fukuyama places trust as social capital, it means social capital whose price is invaluable and capability which springs from a common belief in a society (2002:38). Trust value is required to create a positive community. Therefore, trust is associated with attitude of openness both self and other people. Dance coach in giving dance education at this art studio gave open attitude to students for simulated a good relationship between them (see table 6).

Table 6. Implementation of Social Value

\begin{tabular}{|l|l|l|l|}
\hline \multicolumn{1}{|c|}{ No } & \multicolumn{1}{|c|}{ Value } & \multicolumn{1}{c|}{ Teacher } & \multicolumn{1}{c|}{ Student } \\
\hline 1 & Fairness & $\begin{array}{l}\text { Create a good relationship and } \\
\text { dialogue }\end{array}$ & $\begin{array}{l}\text { Open to receive a suggestion } \\
\text { and advice from the teacher } \\
\text { and more active }\end{array}$ \\
\hline 2 & Responsible & $\begin{array}{l}\text { Take responsibility for } \\
\text { activities learn }\end{array}$ & $\begin{array}{l}\text { Understand knowledge will be } \\
\text { values education }\end{array}$ \\
\hline 3 & Solidarity & Appreciate effort learners & $\begin{array}{l}\text { Appreciate teacher and } \\
\text { learners another }\end{array}$ \\
\hline 4 & Trust & Give chance to learners & Receive chance with trust self \\
\hline
\end{tabular}

Panji Story as an Understanding of Cultural Values

Culture is formed from the basis of the word culture. Culture comes from Sanskrits namely buddhayah, which is the plural form from Buddhi (mind or intellect) and is defined as matters relating to reason of human (Sitohang, 2018:142). Konrad Kebung states that culture 
philosophically is a blend of genuine human nature with various knowledge and knowledge that he get in its motion from its natural state towards civil society (2006:133). Taylor stated that culture is a whole complex that includes knowledge, belief, art, law, morals, habits, and others acquired by humans as members of society (Haviland, 1995:332). So, it can be concluded culture as a whole human knowledge used to understand and interpret the environment and its experiences as guidance in behavior.

Dance education at Andhe-andhe Lumut Kediri art studio shows a culture which is a common property in an arts community passed on to the next young generation. The inheritance is carried out through a learning process through various symbols manifested in verbal and nonverbal forms of various dance material taught by dance coach. Therefore, dance coaches and students have a knowledge of the culture differently by experience and the learning process and the environment. Experience and the learning process is found to be good dance coaches and students alike can develop their abilities continuously. The result of this ability is a form of behavior. A form of dance education behavior in this art studio is dancing. Dancing includes motoric action which involves movement of the whole body and through learning is needed achieving skills (Chang, et al., 2020:2). The achievement of skills is manifested by creating and displaying new works and innovative dance.

\section{Panji Story as an Understanding of Aesthetics Values}

Aesthetics comes from English and the etymology is aesthetikos, which speaks to the problem sensation in the sense of "I sense, I see, I hear, I taste, smell and feel (Subiantoro, 2016:411). Therefore, aesthetics enjoyed by the senses. Beauty in art cannot be separated from individual ability to assess or appreciate objects of beauty. This method done using tools such as sense. The senses include the function of sight, touch, taste, hear, and feeling to do understanding against an object in accordance with the potential and the ability and goals to be achieved. A beautiful work of art objects to be studied by observing and analyze the elements and their form.

Andhe-Andhe Lumut Kediri art studio implements aesthetic value in Panji story through learning both for dance teacher and learners. The dance teacher is one of artist who has abilities and talents, the talent factor 


\section{International Journal of Advanced Multidisciplinary Scientific Research (IJAMSR) ISSN:2581-4281}

provides the sensing weight. That is, dance teacher who uses and has dancing talent from birth can provide ease in identifying shapes and movements in dancing. Learning process results in that knowledge called aesthetic knowledge. Different with students, the talent factor is not a major factor because the main purpose of dance education, namely learning the art of dance through sensing training or objectification aesthetics. However, it is well understood for dance teacher, but through education art that gives more or facilitate students with exercises and appreciation can encourage students to create works of art through the experiences. Experience obtained through learning the art of dance can deepen understanding of beauty in order to cultivate aesthetic awareness through works. Creation learner art is an aesthetic expression previously interpreted and packed into a work of beautiful dance art. The work of art becomes a work that has charactheristics and peculiarity appears in local genious. Some dance art works are the works of this art studio includes Cundrik Asmarantaka dance, Topeng Panji dance, Bedhaya Candrakirana dance, Remo Kedhiren dance, Si Klething dance, Sang Kirana dance, and Gendham Asmaradhana dance.
The aesthetic dimension of learning involves strong mix of thinking skills high, imagination and creativity, learning independent, interpersonal interaction, effective and emotional social attachment (Sajnani, et al., 2020:2). So, from this learning, students as dancer report and remember how they feel about the dance work being studied. That matter in tune with the conclusion that dancers are reporting and remembering feelings, roles and their performance in studying dance is a part of the process (Stevens, et al., 2019: 25). The remembering process is a form to train the sensitivity of student in judge and appreciate beauty. This is also in line with Pratamawati's statement that the activity of assessing and appreciating works of art is included in aesthetic values, where the dance is performed with the aim of providing an aesthetic experience (2016:67). It can be valued and appreciated as a work of art that benefits the audience.

\section{Panji Story as the Cultivation of Moral Values}

Morality is a factor which has a close relationship between the two appearance of moral principles that give guidance for individuals in behave taking into account the 


\section{International Journal of}

Advanced Multidisciplinary Scientific Research (IJAMSR) ISSN:2581-4281

appropriateness of this behavior (Sarwono, 2015:55). The guidance is the result of cultural and community collaboration then passed down from generation to generation. The inheritance process takes place one of the developments of individual. Learning the art of dance as a value of education based on Panji story is a learning process relating to the development of ethical values or morals. KH Dewantara explained that one of the strengths of its cultural values contained in Indonesian art is through learning gending or gamelan. They are supporting elements in the art of dance for reinforce that aims and objectives delivered in the work.

\section{Affective Factors}

Affective factor is a response or an impact or an outcome associated with a program, where the response also includes benefits obtained from the program that is running (Sutopo, 2006:144). Results or the response contains the information in the form of impacts events in a program or activity. This information can be obtained through various observations, assessments and analyze either through works or events experienced. Some people do of course obtain different or mixed results. The diversity of information raises differences which are unconsciously leads to the aims and objectives of this art studio. This diversity is a response from parents of students and teachers towards learning activities and dance education in the studio. This response can be described as follows. Responses from parents of students that through learning dance at this art study become more confident and courageously show themselves in presenting a dance by performing in front of public general; besides that children also become discipline independently and excited to go to studio and practicing dance; the child also becomes more active both in dancing and practicing socialization in the family, environment, school, studios and public. Parents feel that through dance education at children centers, the children have an increase in developing talents, achievements and skills in the art. Parents are also paying more attention to children through their creative development in dancing and having experience in the arts and helping preserving Indonesian culture in the middle current developments.

\section{Conclusion}

Learning dance through the empowerment of local cultural values is important and can revitalize the development of educational vales for young generation. The understanding of the values of education in Panji story as one of 


\section{International Journal of \\ Advanced Multidisciplinary Scientific Research (IJAMSR) ISSN:2581-4281}

Kediri should be able to be connected to the values of the life of students in a broad sense. Delivery of all information is carried out by teacher as a facilitator in learning activities. The teacher must be able to creatively conveys and explain information about the concept and background of the dance stories that are conveyed to students. Therefore, it is necessary to have an appropriate learning strategy to produce student able to understand and implement the values of education in life at large.

Educational values found in the learning dance are: historical, social, culture, aesthetics, and moral values. The values above are expected to be the basis for students to preserve and maintain local cultural values through learning dance. Students understand the importance of local cultural values through learning dance from a cognitive, affective and psychomotor perspective. This knowledge is then followed by young generation being able to implement these values in everyday life both in the family, school and community environment.

\section{References}

1) Alagul, Ozlem. Ferda Gursel\& Gulay Keske. (2012). Dance unit with Physical Literacy. Procedia-Social and Behavioral Sciences 47, 1135-1140.

2) Chang, Michael. Nicholas O'Dwyer. Roger Adams \& Stephen Cobley. (2020). Wholebody Kinematics and Coordination in a Complex Dance Sequence: Differences Across Skill Levels. Human Movement Sciences 69, 102564, 1-12.

3) Fukuyama, Francis. (2002). Trust: Kebajikan Sosial dan Penciptaan Kemakmuran (Terjemahan Ruslani. Yogyakarta: Qalam.

4) Gilligan, Carol. (1997). Dalam Suara yang Lain, Etika Kepedulian. Jakarta: Pustaka Tangga.

5) Haviland. (1995). Antropologi Jilid 2. Jakarta: Erlangga.

6) Huda, Miftahul. (2013). Model-model Pengajaran dan Pembelajaran. Yogyakarta: Pustaka Pelajar.

7) Indrayuda. (2016). The Existance of Local Wisdom Value Through Minangkabau Dance Creation Representation in Present Time. Harmonia Journal of Arts Research And Education, 16(2), 143-152.

8) Jalaluddin\& Idi Abdullah. (2018). Filsafat Pendidikan: Manusia, Filsafat dan Pendidikan. Depok: PT Rajagrafindo Persada.

9) Kebung, Konrad. (2006). Manusia dan Diri yang Utuh. Flores: Nusa Indah.

10) Nuryani, Wenti. Suminto. \& Dwi S. (2020). Nilai-nilai Pendidikan Tata Busana dan Rias Srimpi Pandhelori dalam Perspektif Hermeneutik. Panggung 30(2), 307-324.

11) Poerbatjaraka. (1968). Tjeritera Pandji Dalam Perbandingan. Djakarta: PT Gunung Agung.

12) Pratamawati, Endang Wara S. (2016). Malang Mask Puppet Presentation Structure Arrangement of the Rabine Panji as Cultural Tourism Commodity in Malang Regency East Java. Harmonia Journal of Arts Research And Education, 16(1), 66-74. 
Vol 3, Issue 10, 2020 Imfact Factor:2.58 DOI: https://doi.org/10.31426/ijamsr.2020.3.10.3815

13) Resi, Laras Ambika. (2019). Pendidikan Seni Tari Sanggar Seni Sarwi Retno Budaya Surakarta Sebagai Pengembangan Karakter Anak. Tesis. Universitas Sebelas Maret, Surakarta, Indonesia.

14) Sajnani, Nisha. Christine Mayor\& Heather Tillberg-Webb. (2020). Aesthetic Presense: The Role of the Arts in the Education of Creative Arts Therapist in the Classroom and Online. The Arts in Psychoterapy 69, 101668, 1-9.

15) Sanggar Kesenian Andhe-andhe Lumut Kediri. (2019). Akta Kenotariatan Pendirian Lembaga Pendidikan Nonformal. Kediri.

16) Sanusi, Achmad. (2015). Sistem Nilai. Jakarta: Nuansa Cendikia.

17) Sarwono, Sarlito W. (2015). Psikologi Lintas Budaya. Depok: PT Rajagrafindo Persada.

18) Sicherl- Kafol, Barbara\& Olga Denac. (2010). The Importance of Interdisciplinary Planning of the Learning Process. Procedia Social and Behavioral Sciences 2, 4695-4701
19) Sitohang, Kasdin. (2018). Filsafat Manusia. Yogyakarta: PT Kanisius.

20) Stevens, Catherine J. Kim Vincs. Scott de Lahunta\& Elizabeth Old. (2019). Longterm Memory for Contemporary Dance is Distributed and Collaborative. Acta Psychologica 194, 17-27.

21) Subiantoro, Ign Herry. (2016). Estetika, Seren taun Antara Seni, Ritual dan Kehidupan. Panggung, 26 (4), 407- 419.

22) Sugeng\& Nur Setiyani. (2019). Wawancara dengan Pendiri Sanggar. Kediri: Record

23) Sugiyono. (2019). Metode Penelitian Kuantitatif, Kualitatif dan R\&D. Bandung: CV Alfabeta

24) Sutopo, H.B. (2006). Metodologi Penelitian Kualitatif Dasar Teori dan Terapannya dalam Penelitian. Surakarta: UNS.

25) Sööt, Anu\& Ele Viskus. (2014).

Contemporary Approaches to Dance Pedagogy- the Challenges of the $21^{\text {st }}$ Century. Procedia-Social Behavioral Sciences 112, 290-299. 